Check for updates

Cite this: RSC Adv., 2018, 8, 16663

Received 28th March 2018 Accepted 27th April 2018

DOI: $10.1039 / c 8 r a 02702 a$

rsc.li/rsc-advances

\section{A new efficient domino approach for the synthesis of pyrazolyl-phthalazine-diones. Antiradical activity of novel phenolic products $\uparrow$}

\author{
Dušica Simijonović, (DD *a Zorica D. Petrović, (DD a Vesna M. Milovanović, (D) ${ }^{a}$ \\ Vladimir P. Petrović (DD a and Goran A. Bogdanović (D) ${ }^{\mathrm{b}}$
}

Pyrazolyl-phthalazine-dione derivatives (PPDs) were synthetized in the ionic liquid catalyzed one-pot multicomponent reaction of acetylacetone, 2,3-dihydrophthalazine-1,4-dione, and different aldehydes in moderate to good yields. Six new PPDs were obtained, and the crystal structure of 2-acetyl-1-(4fluorophenyl)-3-methyl-1H-pyrazolo[1,2-b]phthalazine-5,10-dione (PPD-4) was determined. The most interesting structural features of the novel PPD-4 is the formation of a rather short intermolecular distance between the $\mathrm{F}$ atom of one molecule and the midpoint of the neighbouring six-membered heterocyclic ring. This interaction arranges all molecules into parallel supramolecular chains. UV-Vis spectra of all PPDs were acquired and compared to the simulated ones obtained with TD-DFT. All synthetized compounds were subjected to evaluation of their in vitro antioxidative activity using a stable DPPH radical. It was shown that PPD-7, with a catechol motive, is the most active antioxidant, while PPD-9, with two neighbouring methoxy groups to the phenolic $\mathrm{OH}$, exerted a somewhat lower, but significant antioxidative potential. The results of DFT thermodynamical study are in agreement with experimental findings that PPD-7 and PPD-9 should be considered as powerful radical scavengers. In addition, the obtained theoretical results (bond dissociation and proton abstraction energies) specify SPLET as a prevailing radical scavenging mechanism in polar solvents, and HAT in solvents with lower polarity. On the other hand, the obtained reaction enthalpies for inactivation of free radicals suggest competition between HAT and SPLET mechanisms, except in the case of the ${ }^{\circ} \mathrm{OH}$ radical in polar solvents, where HAT is labeled as prefered.

\section{Introduction}

The synthesis of different bioactive nitrogen-containing heterocyclic compounds has always been a topic of synthetic organic chemistry. Among a huge number of nitrogencontaining heterocyclic compounds, heterocycles with phthalazine and pyrazole moieties are especially recognized in the fields of medicine and pharmacy as the integral parts of some drugs. ${ }^{1}$ Such compounds express a broad spectrum of biological activities, such as anticancer, ${ }^{2}$ anticonvulsant, ${ }^{3}$ anti-inflammatory, ${ }^{1 b, 4}$ vasorelaxant, ${ }^{5}$ antitubercular, ${ }^{6}$ antihypertensive, ${ }^{7}$ and antimicrobial activities. ${ }^{5,8 a, b}$ Budralazine, hydralazine,

${ }^{a}$ University of Kragujevac, Faculty of Science, Department of Chemistry, $R$. Domanovića 12, 34000 Kragujevac, Serbia. E-mail: dusicachem@kg.ac.rs; Tel: +381-34-336-223; +381-34-335-039

${ }^{b}$ Vinča Institute of Nuclear Sciences, University of Belgrade, P. O. Box 522, 11001 Belgrade, Serbia

$\uparrow$ Electronic supplementary information (ESI) available: Characterization of compounds, ${ }^{1} \mathrm{H}$ NMR and ${ }^{13} \mathrm{C}$ NMR spectra, melting points, Kohn-Sham orbitals of PDDs, Experimental and simulated UV-Vis spectra. CCDC 1584133. For ESI and crystallographic data in CIF or other electronic format see DOI: $10.1039 / \mathrm{c} 8 \mathrm{ra02702a}$ azelastine, and zaleplon are some of commercially available drugs used in the treatment of vasorelaxation, hypertension, allergic rhinitis, and insomnia (Fig. 1). ${ }^{1}$ Additionally, these compounds serve as new luminescence materials or fluorescence probes. $^{9}$

In view of their importance, several procedures have been reported for the synthesis of phthalazine derivatives, including the reaction of (i) phthalhydrazide and dialkyl acetylenedicarboxylates in the presence of N-heterocycles, ${ }^{\mathbf{1 0}}$ (ii) phthalhydrazide, aromatic aldehydes, and malononitrile, ${ }^{\mathbf{1 1}}$ and (iii)

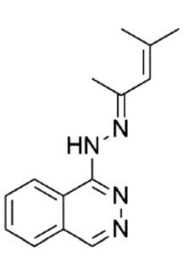

Budralazine

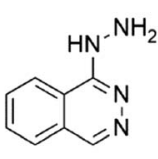

Hydralazine<smiles>CN1CCCC(n2nc(Cc3ccc(Cl)cc3)c3ccccc3c2=O)CC1</smiles>

Azelastine

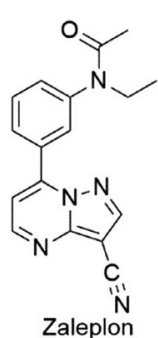

Fig. 1 Structure of some commercially available drugs with phthalazine and pyrazolo moieties. 
palladium-catalyzed 1,3-dipolar cycloaddition of phthalhydrazide with methylenecyclopropanes, vinylidenecyclopropane, and methylenecyclobutane. ${ }^{\mathbf{1 2}}$ Procedures for the synthesis of indazolyl-phthalazine-trione and pyrazolyl-phthalazine-dione derivatives (PPDs), starting from phthalhydrazide, aromatic or aliphatic aldehydes and cyclic or acyclic 1,3-diketones can be found in the literature, but procedures for the synthesis of indazole derivatives prevail. ${ }^{13}$ Various catalytic systems, such as phosphomolybdic acid-silica, ${ }^{13 c} \mathrm{Ce}\left(\mathrm{SO}_{4}\right)_{2} \cdot 4 \mathrm{H}_{2} \mathrm{O},{ }^{13 d}$ dodecylphosphonic acid, ${ }^{13 e}$ heteropoly acids, ${ }^{13 f}$ solid acids, ${ }^{13 g} \mathrm{~N}$-halosulfonamides, ${ }^{13 h}$ silica-sulfuric acid, ${ }^{13 i}$ and $p$-TSA ${ }^{13 j}$ have been used for these reactions. However, the methodologies based on the using these catalysts have a number of serious disadvantages such as toxicity, harsh reaction conditions, and difficulty in the separation of products. Therefore, the synthesis of the complex pyrazolyl-phthalazine derivatives in the presence of ionic liquids (ILs) could be a promising alternative. ${ }^{9,14}$ Due to their ecological acceptability, polarity, and good dissolution ability for a wide range of compounds, ILs are used as catalysts in different organic reactions. ${ }^{15}$ Also, results regarding the usage of economical one-pot multicomponent reactions (MCRs) in the synthesis of PPDs are scarce. ${ }^{16}$ In addition, reactions with acyclic 1,3-diketones for the synthesis of phenolic PPDs cannot be found in the literature. Taking all above stated into account, we wanted to fulfil that gap and design an efficient synergistic protocol for the preparation of different PPDs. With that goal, one-pot three-component reaction was done using reusable diethanolammonium chloroacetate ([HDEA $][\mathrm{ClAc}])$ as IL catalyst, and acetylacetone as acyclic diketone. All obtained compounds were characterized using NMR, IR, and UV-Vis spectroscopy, as well as with TD-DFT. Supramolecular structure of PPD-4 was elucidated using single-crystal X-ray diffraction analysis. Estimation of antioxidative potential of obtained phenolic PPDs was explored experimentally. In addition, preferred radical scavenging mechanism was investigated from thermodynamical aspect, using density functional theory (DFT).

\section{Results and discussion}

Bearing in mind that [HDEA $][\mathrm{ClAc}]$ exerted the best catalytic performance in the Mannich reaction, ${ }^{17}$ we assumed that this catalyst could be efficient for a new, domino, approach for the synthesis of PPDs, starting from acetylacetone, 2,3dihydrophthalazine-1,4-dione and different aldehydes. It is worth pointing out that detailed characterization of this IL was presented before. ${ }^{18}$ To test efficiency of PPDs preparation, onepot reaction of acetylacetone with 2,3-dihydrophthalazine-1,4dione and benzaldehyde was selected as model reaction. Initially, the model reaction was performed without catalyst, and with using diethanolammonium acetate [HDEA][Ac] or [HDEA][ClAc] as catalysts. The influence of different amounts of catalysts $(10,15$, and $20 \mathrm{~mol} \%)$ and different reaction temperatures $\left(100,120,140\right.$, and $\left.160{ }^{\circ} \mathrm{C}\right)$ were investigated, Table 1 . It is worth pointing out, that formation of the product was not observed in uncatalyzed reaction. In the presence of $10 \mathrm{~mol} \%$ of catalyst ([HDEA $][\mathrm{Ac}]$ or $[\mathrm{HDEA}][\mathrm{ClAc}])$ product was formed in low to moderate yield and increase of the catalyst amount to
Table 1 Optimization of the reaction conditions

\begin{tabular}{lll}
\hline Entry & Conditions & Yield $\%$ \\
\hline 1 & No catalyst, $100{ }^{\circ} \mathrm{C}$ & - \\
2 & No catalyst, $120{ }^{\circ} \mathrm{C}$ & - \\
3 & No catalyst, $140{ }^{\circ} \mathrm{C}$ & - \\
4 & No catalyst, $160{ }^{\circ} \mathrm{C}$ & - \\
5 & {$[\mathrm{HDEA}][\mathrm{Ac}] /[\mathrm{HDEA}][\mathrm{ClAc}] 10 \mathrm{~mol} \%, 100{ }^{\circ} \mathrm{C}$} & $20 / 52$ \\
6 & {$[\mathrm{HDEA}][\mathrm{Ac}] /[\mathrm{HDEA}][\mathrm{ClAc}] 10 \mathrm{~mol} \%, 120{ }^{\circ} \mathrm{C}$} & $24 / 58$ \\
7 & {$[\mathrm{HDEA}][\mathrm{Ac}] /[\mathrm{HDEA}][\mathrm{ClAc}] 10 \mathrm{~mol} \%, 140{ }^{\circ} \mathrm{C}$} & $35 / 65$ \\
8 & {$[\mathrm{HDEA}][\mathrm{Ac}] /[\mathrm{HDEA}][\mathrm{ClAc}] 10 \mathrm{~mol} \%, 160^{\circ} \mathrm{C}$} & $33 / 64$ \\
9 & {$[\mathrm{HDEA}][\mathrm{Ac}] /[\mathrm{HDEA}][\mathrm{ClAc}] 15 \mathrm{~mol} \%, 100{ }^{\circ} \mathrm{C}$} & $38 / 70$ \\
10 & {$[\mathrm{HDEA}][\mathrm{Ac}] /[\mathrm{HDEA}][\mathrm{ClAc}] 15 \mathrm{~mol} \%, 120{ }^{\circ} \mathrm{C}$} & $43 / 75$ \\
11 & {$[\mathrm{HDEA}][\mathrm{Ac}] /[\mathrm{HDEA}][\mathrm{ClAc}] 15 \mathrm{~mol} \%, 140{ }^{\circ} \mathrm{C}$} & $48 / 82$ \\
12 & {$[\mathrm{HDEA}][\mathrm{Ac}] /[\mathrm{HDEA}][\mathrm{ClAc}] 15 \mathrm{~mol} \%, 160{ }^{\circ} \mathrm{C}$} & $46 / 80$ \\
13 & {$[\mathrm{HDEA}][\mathrm{Ac}] /[\mathrm{HDEA}][\mathrm{ClAc}] 20 \mathrm{~mol} \%, 100{ }^{\circ} \mathrm{C}$} & $45 / 72$ \\
14 & {$[\mathrm{HDEA}][\mathrm{Ac}] /[\mathrm{HDEA}][\mathrm{ClAc}] 20 \mathrm{~mol} \%, 120^{\circ} \mathrm{C}$} & $50 / 74$ \\
15 & {$[\mathrm{HDE}][\mathrm{Ac}] /[\mathrm{HDEA}][\mathrm{ClAc}] 20 \mathrm{~mol} \%, 140{ }^{\circ} \mathrm{C}$} & $55 / 82$ \\
16 & {$[\mathrm{HDEA}][\mathrm{Ac}] /[\mathrm{HDEA}][\mathrm{ClAc}] 20 \mathrm{~mol} \%, 160{ }^{\circ} \mathrm{C}$} & $57 / 78$ \\
& &
\end{tabular}

$15 \mathrm{~mol} \%$ increased the yield. Further increase of the catalyst amount to $20 \mathrm{~mol} \%$ did not significantly affect the yield of the reactions. Furtherly, influence of the reaction temperature was investigated. Reactions performed at lower temperatures (100 and $120{ }^{\circ} \mathrm{C}$ ) resulted of high amount of the starting material. Increase of temperature to $140{ }^{\circ} \mathrm{C}$ led to the improved yield of the desired product, while further increase of the temperature $\left(160{ }^{\circ} \mathrm{C}\right)$ did not provide better yields. The optimal time for conversion of the starting material was $6 \mathrm{~h}$, and further prolongation did not affect production of the PPDs.

Since catalytic performance of [HDEA][ClAc] was much better, it was used as catalyst for further reactions. Optimized reaction conditions, i.e. $15 \mathrm{~mol} \%$ of [HDEA][ClAc], $140{ }^{\circ} \mathrm{C}$, and $6 \mathrm{~h}$ were used for all investigated reactions, Scheme 1 , Table 2. All PPDs were obtained in moderate to good yields. For their

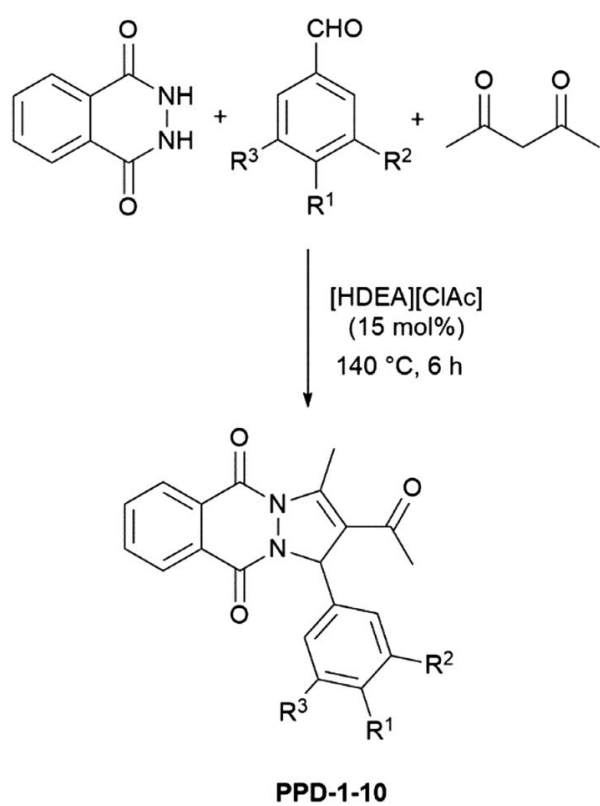

Scheme 1 General synthesis of PPD-1-10 
Table 2 Ionic liquid catalysed synthesis of PPDs ${ }^{a}$

\begin{tabular}{llllll}
\hline Entry & Product & $\mathrm{R}^{1}$ & $\mathrm{R}^{2}$ & $\mathrm{R}^{3}$ & Yield (\%) \\
\hline 1 & PPD-1 & $\mathrm{H}$ & $\mathrm{H}$ & $\mathrm{H}$ & 82 \\
2 & PPD-2 & $\mathrm{CH}_{3}$ & $\mathrm{H}$ & $\mathrm{H}$ & 80 \\
3 & PPD-3 & $\mathrm{Cl}$ & $\mathrm{H}$ & $\mathrm{H}$ & 89 \\
4 & PPD-4 & $\mathrm{F}$ & $\mathrm{H}$ & $\mathrm{H}$ & 87 \\
5 & PPD-5 & $\mathrm{NO}_{2}$ & $\mathrm{H}$ & $\mathrm{H}$ & 90 \\
6 & PPD-6 & $\mathrm{OH}$ & $\mathrm{H}$ & $\mathrm{H}$ & 80 \\
7 & PPD-7 & $\mathrm{OH}$ & $\mathrm{OH}$ & $\mathrm{H}$ & 77 \\
8 & PPD-8 & $\mathrm{OH}$ & $\mathrm{OCH}_{3}$ & $\mathrm{H}$ & 80 \\
9 & PPD-9 & $\mathrm{OH}$ & $\mathrm{OCH}_{3}$ & $\mathrm{OCH}_{3}$ & 70 \\
10 & PPD-10 & $\mathrm{OCH}$ & $\mathrm{OCH}_{3}$ & $\mathrm{OCH}_{3}$ & 72
\end{tabular}

${ }^{a}$ Reaction conditions: acethylacetone : 2,3-dihydrophthalazine-1,4dione : aromatic aldehyde $=2.5: 1: 1$ (molar ratio); catalyst - [HDEA] $[\mathrm{ClAc}](15 \mathrm{~mol} \%)$; temperature $-140{ }^{\circ} \mathrm{C}$; time $-6 \mathrm{~h}$.

isolation column chromatography was used. Ethyl acetate and hexane were used as eluents and environmental friendly organic solvents with low toxicity. Six of ten PPDs are newly synthetized compounds (PPD-4 and PPD-6-10). Among them, only crystals of PPD-4 were suitable for single-crystal X-ray diffraction analysis.

All compounds were characterized with NMR, IR, and UV-Vis spectra, elemental analysis, and melting points. The signals observed in the ${ }^{1} \mathrm{H}$ NMR spectra of synthesized compounds, related to the PPD skeleton, are presented in Table 3, and corresponding atoms labelling in Fig. 2. Chemical shifts in ${ }^{1} \mathrm{H}$ NMR spectra of all PPDs are very similar. Singlet originating from protons of C6 methyl group appears around $2 \mathrm{ppm}$. It is important to emphasize that, in place of expected singlets originating from protons of $\mathrm{C} 1-\mathrm{H}$ and of $\mathrm{C} 4$ methyl group, quartet around $6.5 \mathrm{ppm}$ with $J=1.4 \mathrm{~Hz}$, and doublet about $3 \mathrm{ppm}$ with $J=1.5 \mathrm{~Hz}$ appeared. These peaks represent result of the long-range coupling of proton of asymmetric C1 with protons of C4 methyl group. The protons attached to the aromatic carbons $\mathrm{C} 8-\mathrm{C} 13$ and $\mathrm{C} 15-\mathrm{C} 20$ resonated as multiplets in the range of 7.76-8.39 ppm and 6.66-7.92, while in the case of PPD-9 and PPD-10, the aromatic protons from ring C15-C20 appeared as singlets at 6.70 and $6.68 \mathrm{ppm}$.

The mechanism for the formation of $2 H$-indazolo[2,1- $b]$ phthalazine-triones can be found in the literature, ${ }^{13 b}$ but not

Table 3 Chemical shifts of protons in the PPD skeleton of PPD-1-10 ( ${ }^{1}$ HNMR spectra)

\begin{tabular}{llllll}
\hline & & & & \multicolumn{2}{l}{ ArH } \\
\cline { 5 - 6 } Product & $\mathrm{C} 1-\mathrm{H}$ & $\mathrm{C} 4-\mathrm{H}$ & $\mathrm{C} 6-\mathrm{H}$ & $\mathrm{C} 8-\mathrm{C} 13$ & C15-C20 \\
\hline PPD-1 & 3.08 & 6.50 & 2.09 & $7.79-8.36$ & $7.30-7.48$ \\
PPD-2 & 3.07 & 6.46 & 2.08 & $7.77-8.37$ & $7.15-7.39$ \\
PPD-3 & 3.07 & 6.47 & 2.13 & $7.76-8.36$ & $7.31-7.47$ \\
PPD-4 & 3.08 & 6.50 & 2.12 & $7.78-8.37$ & $6.99-7.53$ \\
PPD-5 & 3.11 & 6.57 & 2.24 & $8.16-8.39$ & $7.67-7.92$ \\
PPD-6 & 3.07 & 6.44 & 2.09 & $7.78-8.40$ & $6.66-7.30$ \\
PPD-7 & 3.00 & 6.33 & 2.05 & $7.77-8.32$ & $6.77-6.91$ \\
PPD-8 & 3.07 & 6.45 & 2.10 & $7.76-8.36$ & $6.87-7.02$ \\
PPD-9 & 3.08 & 6.44 & 2.09 & $7.81-8.38$ & 6.70 \\
PPD-10 & 3.07 & 6.45 & 2.12 & $7.81-8.38$ & 6.68
\end{tabular}

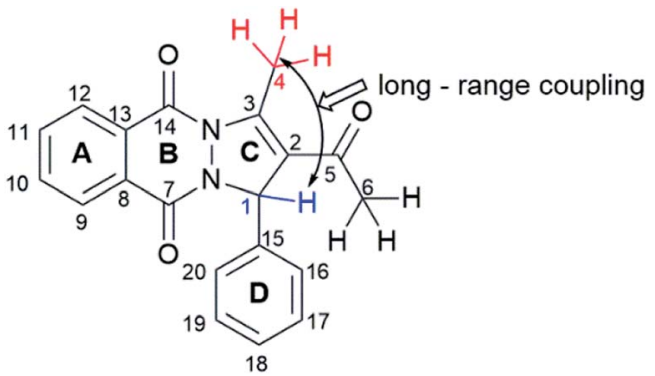

Fig. 2 Skeleton of PPD compounds.

for the formation of pyrazolo[1,2- $b]$ phthalazine-dione. Bearing in mind that the only difference between these reactions is in the usage of diketone, it can be expected that they will obey similar reaction mechanism, Scheme 2 . The reaction starts with the IL catalysed enolization of diketone, and protonation of aromatic aldehyde.

Based on the proposed mechanism, electronic effects of the aldehyde substituents influence on the reaction flow, as well as on the products yield. The nucleophilic attack of the enol form of ketone to the carbonyl group of aldehyde would be facilitated with electron-withdrawing groups positioned on the aromatic ring of the aldehyde (Table 2, entries 3-5) enabling quick formation of the Knoevenagel adduct. Next step of the reaction, i.e. Michael type addition of 2,3-dihydrophthalazine-1,4-dione to the Knoevenagel adduct, will be also favoured with the same type of substitution. After intramolecular cyclization of the Michael adduct, the appropriate PPD is formed. The proposed mechanism agrees with the obtained yields which are reduced in the case of benzaldehyde and electron-donating substituted benzaldehyde (Table 2, entries 1, 2, and 7-10).

\section{UV-Vis spectral characterization of PPD-4}

In all experimental and simulated spectra two major absorption bands appear around $220 \mathrm{~nm}$ and $360 \mathrm{~nm}$, with shoulder appearing around $250 \mathrm{~nm}$ Fig. 3 and S1. $\dagger$ The only exception is in the case of PPD-5, where additional band appears around $300 \mathrm{~nm}$. To be precise, this band is present in absorption spectra of all compounds, but at lower wavelength (around 280 $\mathrm{nm}$ ), as shoulder and with low oscillator strength. It is worth pointing out, that all simulated absorption bands are somewhat redshifted, with the most significant deviation for weak experimental band around $280 \mathrm{~nm}$, which appears around $310 \mathrm{~nm}$ in simulated ones.

To explore which transitions are responsible for the appearance of each absorption band, Kohn-Sham orbitals were constructed, Fig. S2-11, $\dagger$ while electron transitions and corresponding orbital energies are provided in Tables S1 and S2. $\dagger$ For the sake of clarity, parts of all compounds were labelled as shown in Fig. 2. Here, spectrum of PPD-4 will be discussed in detail, while all relevant data for other investigated PPDs are provided in ESI. $\uparrow$ Band at the lowest wavelength $(219 \mathrm{~nm}$ in experimental) is a consequence of several electron transitions with bands positioned at 224.6 and $225.5 \mathrm{~nm}$ in simulated 


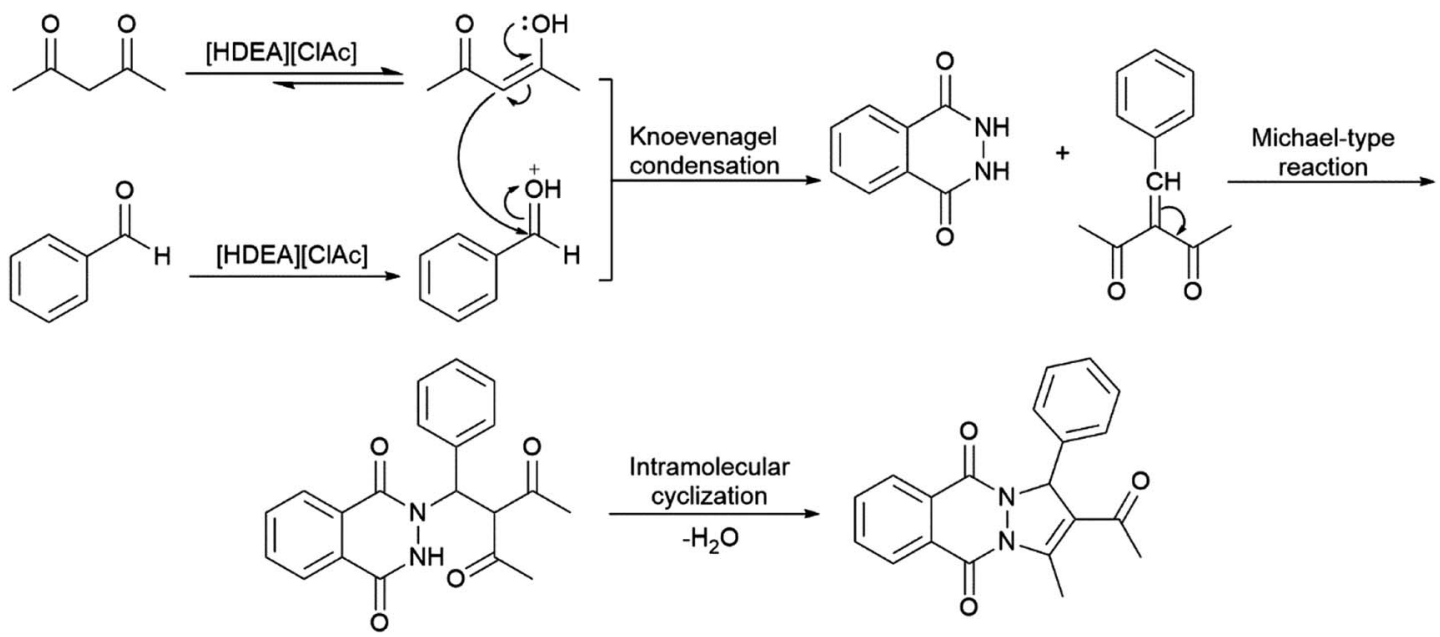

Scheme 2 The suggested mechanism for the considered reaction.

spectra, Fig. 3. The first one is caused by electron transition from HOMO-3 to LUMO+2 orbital, as well as HOMO-7 and HOMO -8 transitions to LUMO+1, while the second one by HOMO-5 and HOMO-7 to LUMO+1 electron transitions, Fig. S5. $\uparrow$ At molecular level, the band at $224.6 \mathrm{~nm}$ is enabled by electron transition from ring $\mathrm{C}$ to the rings $\mathrm{A}$ and $\mathrm{B}$, from the rings $\mathrm{B}$ and $\mathrm{D}$ to the rings $\mathrm{A}, \mathrm{B}, \mathrm{C}$, and acyl group of ring $\mathrm{C}$, and from nitrogen and oxygen atoms of ring $\mathrm{B}$, ring $\mathrm{C}$ to the rings $\mathrm{A}$, $\mathrm{B}, \mathrm{C}$. The band at $225.5 \mathrm{~nm}$ is a consequence of electron transition from rings A and oxygens of ring $\mathrm{B}$ (HOMO-5) and from ring $\mathrm{C}$ and oxygens of ring $\mathrm{B}(\mathrm{HOMO}-7)$ to the rings $\mathrm{A}, \mathrm{B}$, and $\mathrm{C}$. Shoulder appearing around $250 \mathrm{~nm}$ in experimental spectrum is consequence of multiple electron transitions presented with two absorption bands at 244 and $259 \mathrm{~nm}$ in simulated spectrum. Lower wavelength band is product of transitions from HOMO- 6 to LUMO and LUMO+1 (nitrogen and oxygen atoms of ring $\mathrm{B}$, ring $\mathrm{C}$ to the rings $\mathrm{A}, \mathrm{B}, \mathrm{C}$, and acyl group of ring $\mathrm{C}$, as well as to the rings A, B, and C), and HOMO-8 to LUMO electron transition (rings $\mathrm{B}$ and $\mathrm{C}$ to the rings $\mathrm{A}, \mathrm{B}$, and $\mathrm{C}$ ), while the higher wavelength is caused by HOMO-5 to LUMO (ring A and oxygen atoms of ring $\mathrm{B}$ to the to the rings $\mathrm{A}, \mathrm{B}$ ) and $\mathrm{HOMO}-1$ to

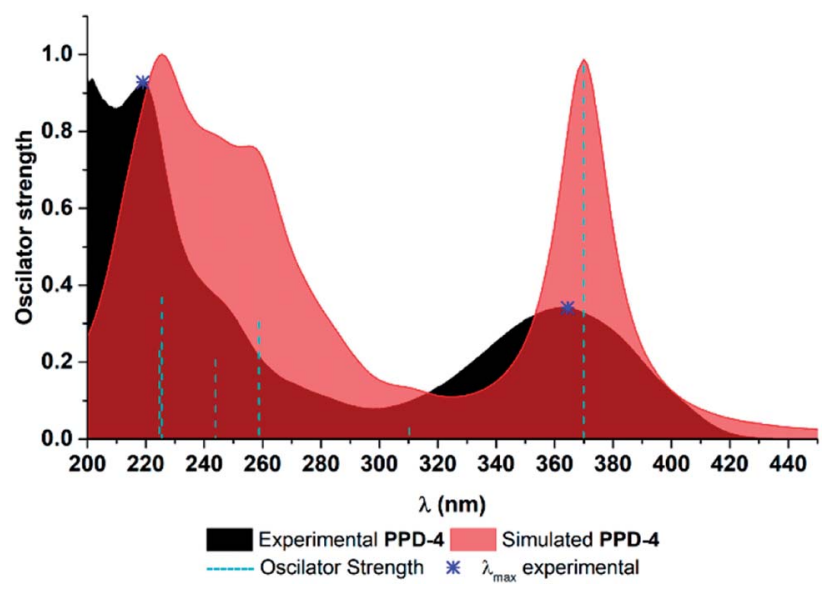

Fig. 3 UV-Vis spectra of PPD-4.
LUMO+1 electron transition (ring $\mathrm{D}$ and oxygen and nitrogen atom of ring $\mathrm{B}$ to the rings $\mathrm{A}, \mathrm{B}$, and $\mathrm{C}$ ). Weak intensity shoulder around $280 \mathrm{~nm}$ appears due to HOMO to LUMO+1 electron transition (from rings $\mathrm{B}, \mathrm{C}$, and acyl group of ring $\mathrm{C}$ to the rings $\mathrm{A}, \mathrm{B}$, and $\mathrm{C}$ ). The highest absorption band around $360 \mathrm{~nm}$ in experimental spectra is a consequence of HOMO to LUMO electron transition (from rings $\mathrm{B}, \mathrm{C}$, and acyl group of ring $\mathrm{C}$ to the rings $\mathrm{A}, \mathrm{B}$, and $\mathrm{C}$ ). Based on the obtained results, one can see that lower wavelength bands (bellow $280 \mathrm{~nm}$ in experimental spectra) are appearing owing to relatively large energetical but relatively small spatial separation, while the higher wavelengths are consequence of relatively smaller energy separation of corresponding HOMO and LUMO. It is worth pointing out that bands in UV-Vis spectra of all other PPDs are consequence of similar electron transitions. As mentioned above, the only deviation is in the case of UV-Vis spectra of PPD-5, where the presence of electron withdrawing nitro group on the ring $\mathrm{D}$ is responsible for redshifted appearance of this band as one peak around $300 \mathrm{~nm}$ (instead of small shoulder like in other cases). Namely, in the spectra of PPD-5, this band is enabled by electron transition from HOMO-2 to LUMO (rings A and D to the ring $\mathrm{D}$ including nitro group), which is obviously favoured by electron accepting nature of nitro group.

\section{Crystal structure of PPD-4}

Single-crystal X-ray diffraction analysis showed that PPD-4 crystallizes with two crystallographically independent molecules in an asymmetric unit of the centrosymmetric Pbca space group. These two geometrically very similar molecules are designated in Fig. 4 as molecules A and B.

Corresponding bond lengths in two molecules are mutually similar as presented in Table 4 . The only chiral atom in PPD-4 forms the $\mathrm{C} 1-\mathrm{C} 15(1.52 \AA)$ and $\mathrm{C} 1-\mathrm{C} 2(1.51 \AA)$ bonds which are the longest $\mathrm{C}-\mathrm{C}$ bonds in both molecules. The $\mathrm{C} 2-\mathrm{C} 3$ bond with bond length of $1.34 \AA$ is the shortest $\mathrm{C}-\mathrm{C}$ bond and can be assigned as only localized $\mathrm{C}-\mathrm{C}$ double bond in PPD-4, Table 4. It is interesting to compare four $\mathrm{N}-\mathrm{C}$ bonds since they exhibit 


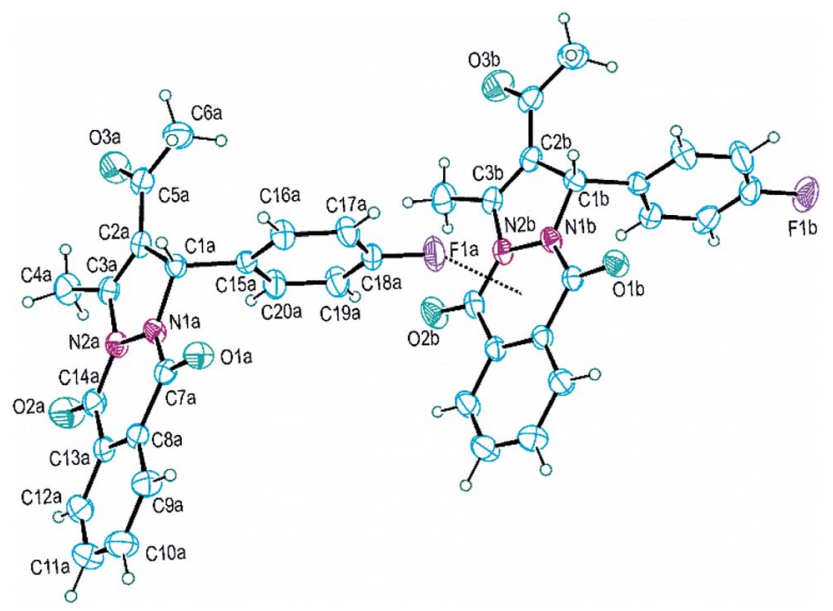

Fig. 4 Molecular structure and atom-numbering scheme of two independent molecules of PPD-4 (molecule A left, molecule B right). Displacement ellipsoids are drawn at the $30 \%$ probability level. Dotted line represents $\mathrm{Fla} \cdots \mathrm{Cg} 1$ interaction (Cg1 is midpoint of the N1-C7C8-C13-C14-N2 ring).

Table 4 Selected bond distances $(\AA)$ in the crystal structure of PPD-4

\begin{tabular}{lll}
\hline & Molecule A & Molecule B \\
\hline F1-C18 & $1.366(2)$ & $1.365(3)$ \\
N1-N2 & $1.411(2)$ & $1.410(2)$ \\
N1-C1 & $1.475(3)$ & $1.473(3)$ \\
N1-C7 & $1.344(3)$ & $1.344(3)$ \\
N2-C3 & $1.402(3)$ & $1.401(3)$ \\
N2-C14 & $1.376(3)$ & $1.380(3)$ \\
O1-C7 & $1.227(2)$ & $1.229(2)$ \\
O2-C14 & $1.220(3)$ & $1.222(3)$ \\
O3-C5 & $1.219(3)$ & $1.221(3)$ \\
C1-C2 & $1.514(3)$ & $1.509(3)$ \\
C1-C15 & $1.518(3)$ & $1.519(3)$ \\
C2-C3 & $1.345(3)$ & $1.343(3)$ \\
C2-C5 & $1.467(3)$ & $1.474(3)$ \\
C7-C8 & $1.476(3)$ & $1.468(3)$ \\
C13-C14 & $1.461(3)$ & $1.463(3)$ \\
& &
\end{tabular}

rather wide range of values (from 1.34 to $1.48 \AA$ ) and considering that the $\mathrm{N} 1$ and $\mathrm{N} 2$ atoms form the N1-N2 bond and have very similar neighbourhood, Fig. 4 . The nitrogen atoms are directly linked to two equivalent and geometrically equally placed carbonyl groups (O1-C7 and $\mathrm{O} 2-\mathrm{C} 14)$ but in both molecules the N1-C7 bond is somewhat shorter than corresponding N2-C14, Table 4. Bond length difference between the $\mathrm{N} 1-\mathrm{C} 1$ and corresponding $\mathrm{N} 2-\mathrm{C} 3$ bond is larger and can be explained by different character of the $\mathrm{C} 1$ and $\mathrm{C} 3$ atoms.

All non-hydrogen atoms with exception of the substituted C15-C20 phenyl ring are approximately coplanar. Therefore, nineteen $\mathrm{C}, \mathrm{O}$ and $\mathrm{N}$ atoms form very large planar system regardless of the fact that many of them form single bonds. Thus, the heterocyclic $\mathrm{N} 1-\mathrm{C} 7-\mathrm{C} 8-\mathrm{C} 13-\mathrm{C} 14-\mathrm{N} 2$ ring exhibits root-mean-square deviation of fitted atoms from mean plane less than $0.03 \AA$ in both molecules. Dihedral angle between this heterocyclic ring and the $\mathrm{C} 8-\mathrm{C} 13$ phenyl ring is 1.2(2) and
1.1(2) ${ }^{\circ}$ for molecules A and B respectively. The five-membered heterocyclic ring is the most puckering ring in PPD-4, but it also could be accepted as approximately planar since that torsion angles within the ring do not exceed the value of $5^{\circ}$.

Although on first view two molecules have very similar conformation there are some structural differences, Fig. 4 . The largest difference is in the orientation of the $\mathrm{C} 15-\mathrm{C} 20$ phenyl ring regarding to the rest of molecule and it can be illustrated by the N1-C1-C15-C20 torsion angle; 65.4(3) and 56.8(3) for molecules A and B respectively. Also, the $\mathrm{C} 7-\mathrm{N} 1-\mathrm{N} 2-\mathrm{C} 14$ angles have significantly different values; $-9.1(3)$ and $-2.8(3)^{\circ}$ for $\mathrm{A}$ and B respectively.

The most interesting structural characteristic in crystal structure of PPD-4 is the formation of rather short F1a $\cdots \mathrm{Cg} 1 \mathrm{~b}$ and $\mathrm{F} 1 \mathrm{~b} \cdots \mathrm{Cg} 1 \mathrm{a}$ intermolecular distances between $\mathrm{F}$ atom and neighbouring six-membered heterocyclic ring with two carbonyl groups (Cg1 is midpoint of the $\mathrm{N} 1-\mathrm{C} 7-\mathrm{C} 8-\mathrm{C} 13-\mathrm{C} 14-\mathrm{N} 2$ ring), Fig. 4 and 5. These intermolecular interactions should not be treated as coincidental since the $\mathrm{F} 1 \cdots \mathrm{Cg} 1$ distance is shorter than $3 \AA$ ( 2.93 and $2.88 \AA$ for F1a and F1b respectively) and all molecules form extended chains along $c$-crystallographic axis using this interaction, Fig. 5. Regardless of the presence of two aromatic rings, the molecules of PPD-4 do not participate in $\pi$ $\pi$ interactions but they form several weak $\mathrm{C}-\mathrm{H} \cdots \mathrm{O}$ intermolecular hydrogen bonds shown in Table 5 . The $\mathrm{O} 3$ carbonyl atom in both independent molecules forms $\mathrm{C} 4-\mathrm{H} \cdots \mathrm{O} 3$ intramolecular H-bond, Table 5.

\section{DPPH radical scavenging activity}

All synthetized compounds PPD-1-10 were subjected to evaluation of their in vitro antioxidative activity. The radical scavenging ability of the compounds was tested against the 1,1diphenyl-2-picryl-hydrazyl (DPPH) stable free radical, Tables 6 and S3.† Among the tested substances, compounds PPD-7 and PPD-9, obtained from protocatechualdehyde and syringaldehyde, exhibited the best scavenging activities, with $\mathrm{IC}_{50}$ values of 4.1 and $14.6 \mu \mathrm{M}$, Table 6. PPD-8, obtained from vanillin, exerted lower activity, while PPD-1-6 and PPD-10 didn't express DPPH scavenging activity.

Obtained results are in accordance with the literature data that the antioxidative capacity of phenolic compounds depends on the type, number, and position of neighbouring groups $(\mathrm{OH}$, $\mathrm{OR}, \mathrm{NH}_{2}$ ) to the phenolic hydroxy group. ${ }^{19}$ Resonance and electron donating effects of these groups increase the stability of the formed phenoxy radical. This stabilisation effect is the most pronounced in catechol-like compounds, where the hydroxy group contributes to the homolytic cleavage of the neighbouring $\mathrm{O}-\mathrm{H}$ bond, and has the ability to form a hydrogen bond with formed phenoxy radical. ${ }^{20}$ In addition, experimental and theoretical studies have shown that stabilization by $\mathrm{H}^{-}$ bonding is more pronounced in formed $o$-semiquinone radical than in parent catechol. ${ }^{21}$ Our results of antioxidative capacity of PPDs are in perfect agreement with above mentioned findings. Namely, PPD-7, with catechol motive, is the most active antioxidant, while PPD-9, with two neighbouring methoxy groups to the phenolic $\mathrm{OH}$, exerted somewhat lower, but 


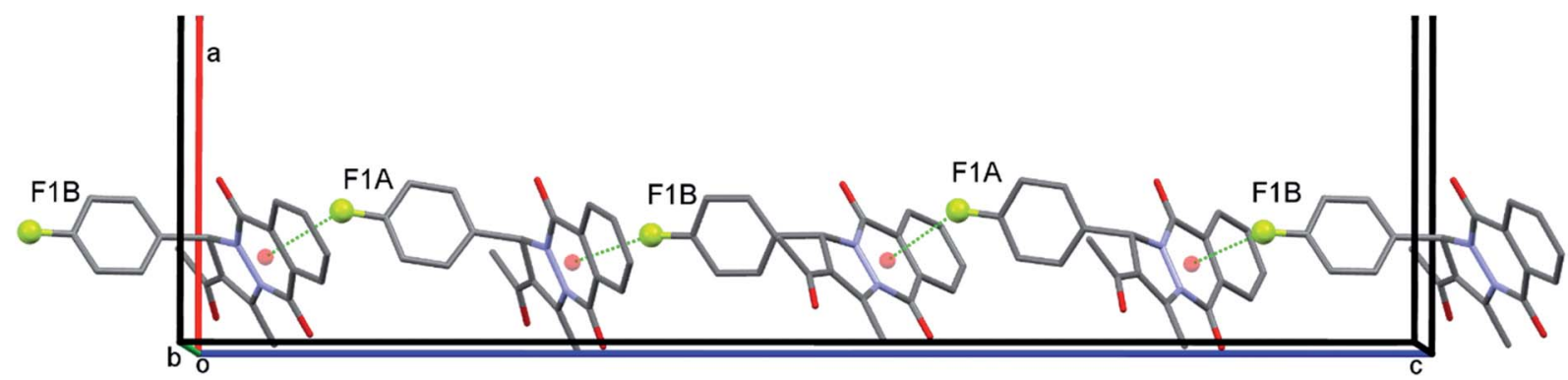

Fig. 5 Crystal lattice fragment of PPD-4 representing formation of supramolecular chain along c-crystallographic axis using F1 ‥Cg1 intermolecular interactions. The Cg1 (labelled by red circle) is midpoint of six-membered heterocyclic ring. $\mathrm{H}$ atoms are omitted for clarity.

significant antioxidative potential. Compound PPD-8, with one methoxy group in ortho-position, expressed moderate activity.

\section{Antioxidative mechanisms and free radical scavenging mechanisms of PPDs with different free radicals}

It is well known that there are several possible mechanisms of radical scavenging: Hydrogen Atom Transfer (HAT), Single Electron-Proton Transfer (SET-PT), and Sequential Proton-Loss Electron-Transfer (SPLET). To determine the most probable mechanism of radical scavenging of phenolic compounds PPD7-9, DFT and thermodynamic approach were employed. Insight into the most probable reaction pathway in the absence of free radicals from the thermodynamic point of view can be accessed by calculating Bond Dissociation Enthalpy (BDE), Ionisation Potential (IP), and Proton Abstraction (PA) energies. ${ }^{22}$ On the other hand, the scavenging mechanisms are highly influenced by the electronic properties of the scavenged free radical species. ${ }^{22 g}$ Therefore, the reaction enthalpies $\left(\Delta_{\mathrm{r}} H\right)$ were calculated for the reactions of phenolic PPDs with each of the eight selected free radicals: hydroxy $\left({ }^{\circ} \mathrm{OH}\right)$, hydroperoxy $\left({ }^{\circ} \mathrm{OOH}\right)$, methylperoxy $\left(\mathrm{CH}_{3}-\mathrm{O}-\mathrm{O}^{\circ}\right)$, superoxide radical anion $\left(\mathrm{O}_{2}{ }^{\cdot-}\right)$, methoxy $\left(\cdot{ }^{\circ} \mathrm{OCH}_{3}\right)$, tert-butoxy $\left({ }^{\circ} \mathrm{OC}\left(\mathrm{CH}_{3}\right)_{3}\right)$, vinyl peroxy $\left(\mathrm{CH}_{2}=\right.$ $\mathrm{CH}-\mathrm{O}-\mathrm{O}^{\circ}$ ), and DPPH. Obtained values for $\Delta H_{\mathrm{BDE},} \Delta H_{\mathrm{IP}}$ and $\Delta H_{\mathrm{PDE}}, \Delta H_{\mathrm{PA}}$ and $\Delta H_{\mathrm{ETE}}$ indicate which of HAT, SET-PT, and SPLET mechanism prevails, respectively. Details on calculation of thermodynamic parameters in the absence and in the presence of free radicals are well known in the literature. ${ }^{22}$ The thermodynamic parameters were obtained by optimization of all relevant species in three solvents. Here we present results obtained in methanol (Table 6), since it was used for experimental DPPH assay, while results regarding benzene (to mimic non-polar environment) and water are provided in Tables S4 and S5 of ESI. $\uparrow$ Selection of radicals has been made on their presence in living cell, and their chemical behaviour within the cell. ${ }^{23}$ Namely, $\mathrm{O}_{2}{ }^{-}$is formed as a product of respiration in living cells, ${ }^{24}$ and is susceptible to protonation at $\mathrm{pH}$ lower than 4.8 , yielding more reactive ${ }^{\circ} \mathrm{OOH}$ radical. In addition, $\mathrm{O}_{2}{ }^{-}$undergoes dismutation to give hydrogen peroxide $\left(\mathrm{H}_{2} \mathrm{O}_{2}\right)$, which via Fenton and Haber-Weiss reactions produces the ${ }^{\circ} \mathrm{OH}$ radical. This powerful oxidant, in the presence of air, reacts with hydrocarbons producing peroxy radicals, which are furtherly transformed into the alkoxy radicals. DPPH was selected because it was used in experimental assay.

Inspection of Tables $6, \mathrm{~S} 4$, and $\mathrm{S} 5 \dagger$ undoubtedly provided evidence that one can eliminate SET-PT as working mechanism in the absence and in the presence of free radicals, and in all investigated solvents. Obtained values for IP and $\Delta H_{\mathrm{IP}}$ are significantly higher than those obtained for thermodynamic parameters and reaction enthalpies of HAT and SPLET mechanisms. On the other hand, BDE is considerably larger than PA in polar solvents, pointing out that all investigated PPDs will obey SPLET mechanism, while in environment with low polarity HAT. This is consistent with plausible heterolytic bond dissociation in polar solvents and homolytic in non-polar. ${ }^{25}$ Namely, product of HAT mechanism is radical formed from each of PPDs, while in the case of SPLET, the first step is proton abstraction and formation of corresponding anions.

Similarly to the case of mechanism of action in the absence of free radicals, in the presence of free radicals preferred route of radical scavenging is highly influenced by solvent polarity. At

Table 5 Selected $\mathrm{C}-\mathrm{H} \cdots \mathrm{O}$ hydrogen bonds in the crystal structure of PPD-4 with the $\mathrm{H} \cdots \mathrm{O}$ distance shorter than $2.6 \AA$ and the $\mathrm{C}-\mathrm{H} \cdots \mathrm{O}$ angle larger than $110^{\circ}$

\begin{tabular}{llllll}
\hline $\mathrm{C}-\mathrm{H} \cdots \mathrm{O}$ & $\mathrm{C}-\mathrm{H}(\AA)$ & $\mathrm{C} \cdots \mathrm{O}(\AA)$ & $\mathrm{H} \cdots \mathrm{O}(\AA)$ & $\mathrm{C}-\mathrm{H} \cdots \mathrm{O}\left({ }^{\circ}\right)$ & Symmetry code for O \\
\hline $\mathrm{C} 1 \mathrm{a}-\mathrm{H} 1 \mathrm{~A} \cdots \mathrm{O} 1 \mathrm{a}$ & 0.98 & $3.452(3)$ & 2.49 & 166 & $-x+0.5, y+0.5, z$ \\
$\mathrm{C} 9 \mathrm{a}-\mathrm{H} 9 \mathrm{a} \cdots \mathrm{O} 1 \mathrm{a}$ & 0.93 & $3.234(3)$ & 2.54 & 132 & $-x+0.5, y-0.5, z$ \\
$\mathrm{C} 12 \mathrm{~b}-\mathrm{H} 12 \mathrm{~b} \cdots \mathrm{O} 2 \mathrm{a}$ & 0.93 & $3.203(3)$ & 2.47 & 136 & $-x, y-0.5,-z+1.5$ \\
$\mathrm{C} 4 \mathrm{a}-\mathrm{H} 4 \mathrm{a} 1 \cdots \mathrm{O} 3 \mathrm{a}$ & 0.96 & $2.936(3)$ & 2.23 & 130 & $x, y, z$ \\
$\mathrm{C} 4 \mathrm{a}-\mathrm{H} 4 \mathrm{a} 3 \cdots \mathrm{O} 3 \mathrm{a}$ & 0.96 & $3.293(3)$ & 2.59 & 130 & $-x, y-0.5,-z+1.5$ \\
$\mathrm{C} 1 \mathrm{~b}-\mathrm{H} 1 \mathrm{~b} \cdots \mathrm{O} 1 \mathrm{~b}$ & 0.98 & $3.421(3)$ & 2.45 & 173 & $-x+0.5, y+0.5, z$ \\
$\mathrm{C}$ - $\mathrm{b}-\mathrm{H} 9 \mathrm{~b} \cdots \mathrm{O} 1 \mathrm{~b}$ & 0.93 & $3.347(3)$ & 2.58 & 140 & $-x+0.5, y-0.5, z$ \\
$\mathrm{C} 4 \mathrm{~b}-\mathrm{H} 4 \mathrm{~b} 1 \cdots \mathrm{O} 3 \mathrm{~b}$ & 0.96 & $2.943(3)$ & 2.23 & 130 & $x, y, z$
\end{tabular}


Paper

(⿸丆口

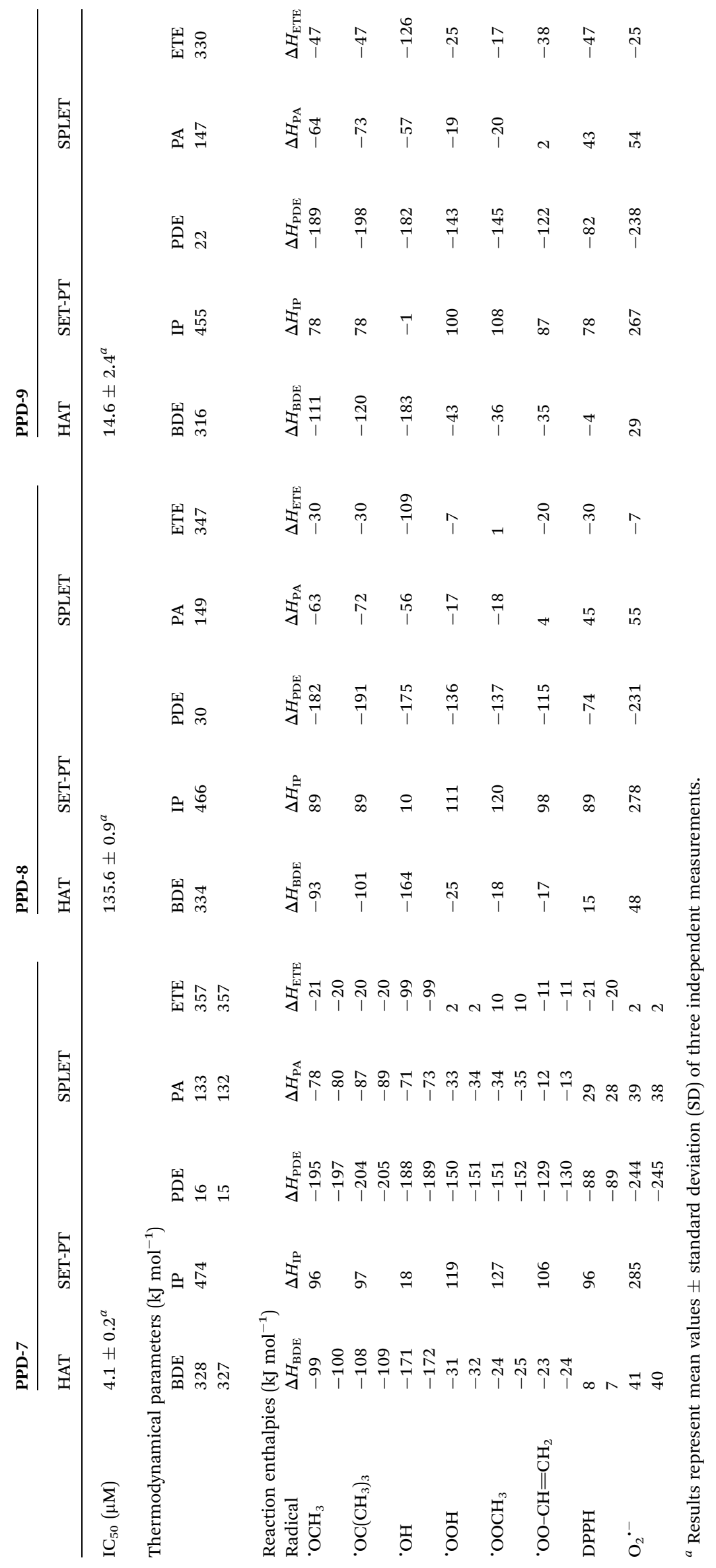


first glance, based on $\Delta_{\mathrm{r}} H_{\mathrm{BDE}}$ and $\Delta_{\mathrm{r}} H_{\mathrm{PA}}$ enthalpies obtained in polar solvents (methanol and water), HAT seems to be preferred mechanism, while in the low polar media SPLET. However, deeper insight in reaction enthalpies for hydrogen atom and proton abstraction in Tables $6, \mathrm{~S} 4$, and $\mathrm{S} 5 \dagger$ proved this to be correct only in the case of ${ }^{\circ} \mathrm{OH}$ radical, and only in the case of polar solvents. Here, difference between $\Delta_{\mathrm{r}} H_{\mathrm{BDE}}$ and $\Delta_{\mathrm{r}} H_{\mathrm{PA}}$ values is significant, designating HAT as preferred mechanism. In the case of alkoxy radicals $\left({ }^{\circ} \mathrm{OCH}_{3}\right.$ and $\left.{ }^{\circ} \mathrm{OC}\left(\mathrm{CH}_{3}\right)_{3}\right)$ and peroxy radicals ( ${ }^{\circ} \mathrm{OOH}, \mathrm{CH}_{3}-\mathrm{O}-\mathrm{O}^{\circ}$, and $\mathrm{CH}_{2}=\mathrm{CH}-\mathrm{O}-\mathrm{O}{ }^{\circ}$ ) this difference is less pronounced, indicating that there is competition between HAT and SPLET mechanisms. In the case of DPPH radical, low positive values of reaction enthalpies suggest slow interaction of examined compounds with this radical. In addition, $\Delta_{\mathrm{r}} H_{\mathrm{PA}}$ values are higher than $\Delta_{\mathrm{r}} H_{\mathrm{BDE}}$ in all solvents and for all PPDs, indicating HAT as less endothermic and therefore preferred scavenging route of this radical. In the case of $\mathrm{CH}_{2}=$ $\mathrm{CH}-\mathrm{O}-\mathrm{O}^{\bullet}$ radical, positive values of $\Delta_{\mathrm{r}} H_{\mathrm{PA}}$ for the reactions in methanol and water, express endothermic nature of the SPLET mechanism, while $\Delta_{\mathrm{r}} H_{\mathrm{BDE}}$ are negative, impaling HAT as more probable mechanism. It is worth pointing out, that in all examined cases and in all solvents, enthalpies of the reactions with $\mathrm{O}_{2}{ }^{--}$are the highest, suggesting that this radical will be scarcely quenched. ${ }^{26}$

\section{Conclusions}

A new efficient, ionic liquid [HDEA][ClAc] catalysed, synthesis of PPDs has been realized. The products were obtained in moderate to good yields, depending on the aldehyde substitution. Namely, electron-withdrawing groups provided higher yields of obtained products PPD-3-5. Six PPDs (4, 6, 7, 8, 9, and 10) are reported here for the first time. All obtained compounds were characterized using NMR, IR, and UV-Vis spectroscopy, and for PPD-4 the crystal structure was determined using singlecrystal X-ray diffraction analysis. It was found that this compound crystallizes with two crystallographically independent molecules and their structural properties are analysed in detail. The most interesting structural characteristic in the crystal structure of PPD-4 is the formation of rather short intermolecular distances (2.93 and $2.88 \AA$ for F1a and F1b respectively) between $\mathrm{F}$ atom and midpoint of neighbouring sixmembered heterocyclic ring, which is the cause of the formation of parallel one-dimensional supramolecular chains.

All synthetized PPD derivatives were screened for DPPH radical scavenging potential. PPD-7 and PPD-9, with catechol and syringic moiety, excreted excellent antioxidant activity, while compound PPD-8 with vanillic moiety moderate. Thermodynamical data obtained from DFT study specify SPLET as prevailing mechanism in polar solvents, while in environment with low polarity HAT. On the other hand, pronounced differences in reaction enthalpies for inactivation of ${ }^{\circ} \mathrm{OH}$ radical in polar solvents denote HAT as dominant mechanism. However, in all other cases and in solvents with high and low polarity, obtained reaction enthalpies suggest competition between HAT and SPLET mechanisms.

\section{Experimental}

The compounds acetic acid, chloroacetic acid, 2,3dihydrophthalazine-1,4-dione, benzaldehyde, 4-fluorobenzaldehyde, 4-chlorobenzaldehyde, 4-methylbenzaldehyde, 4-nitrobenzaldehyde, 4-hydroxybenzaldehyde, 3,4-dihydroxybenzaldehyde, 3,4,5-trimethoxybenzaldehyde, vanillin, syringaldehyde and acetylacetone were obtained from Aldrich Chemical Co. Diethanolamine (DEA) was purchased from Fluka. All common chemicals were of reagent grade. The UV-Vis spectra were measured at room temperature within the 200$500 \mathrm{~nm}$ range on the Agilent Technologies, Cary 300 Series UVVis Spectrophotometer. A solution of $2.5 \times 10^{-5} \mathrm{M}$ of each compound was prepared in methanol and then $2 \mathrm{~mL}$ of the corresponding solution was injected into the $10 \mathrm{~mm}$ quartz cell and recorded spectrum. The IR spectra were recorded on a Perkin-Elmer Spectrum One FT-IR spectrometer using the thin film technique and $\mathrm{KBr}$ plates. The ${ }^{1} \mathrm{H}$ NMR and ${ }^{13} \mathrm{C}$ NMR spectra were run in $\mathrm{CDCl}_{3}$ and $\mathrm{CD}_{3} \mathrm{OD}$ on a Varian Gemini 200 $\mathrm{MHz}$ spectrometer. Melting points were determined on a MelTemp capillary melting points apparatus, model 1001. Elemental microanalysis for carbon, hydrogen, and nitrogen were performed at the Faculty of Chemistry, University of Belgrade.

\section{Synthesis of [HDEA][Ac] and [HDEA][ClAc]}

The procedure for synthesis of the [HDEA][Ac] and [HDEA] [ClAc], as well as their corresponding spectral characterization are given in ref. 18 .

\section{General procedure for synthesis of PPDs}

A mixture of acethylacetone (2.5 mmol), 2,3dihydrophthalazine-1,4-dione (1 mmol), aromatic aldehyde (1 $\mathrm{mmol}$ ), and $15 \mathrm{~mol} \%$ [HDEA][ClAc] was heated at $140{ }^{\circ} \mathrm{C}$ for $6 \mathrm{~h}$. Reaction progress was monitored using thin layer chromatography (TLC). After completion of the reaction, the resulting mixture was dissolved in ethyl acetate and washed with water. The residues obtained by ethyl acetate evaporation were purified by silica gel chromatography using ethyl acetate/hexane (2:1) as eluent. All products (PPD-1-10) were characterized with elemental analysis, melting point, ${ }^{1} \mathrm{HNMR},{ }^{13} \mathrm{CNMR}$ and IR spectra. The characterizations of the new compounds are given in main part of the manuscript, while for known compounds in ESI, $\dagger$ as well as ${ }^{1} \mathrm{H}$ and ${ }^{13} \mathrm{C}$ NMR spectra for all compounds.

\section{Recycling experiment}

After completion of the reaction, the mixture was dissolved in ethyl acetate. Resulting ethyl acetate mixture was washed several times with water. Upon this, separated water parts were combined and evaporated. After water evaporation, [HDEA] [ClAc] residue was reused directly without further purification. So recovered catalyst was reused four times in new experiments, without significant decrease of the product yields. 


\section{Density functional theory calculations}

The Gaussian 09 program package was used to perform all calculations. ${ }^{27}$ The equilibrium geometries of all compounds, its radical cation, radicals and anions, as well as all other species that participate in the reactions of all studied mechanisms were calculated using the B3LYP functional in conjunction with the $6-311+\mathrm{G}(\mathrm{d}, \mathrm{p})$ basis set. $^{28}$ The influence of methanol $(\varepsilon=32.6)$, water $(\varepsilon=78.4)$, and benzene $(\varepsilon=2.3)$ as solvents was estimated, using SMD model as implemented in Gaussian $09 .{ }^{27,29}$ To confirm that all structures are local minima, frequency calculations were done. The optimized geometries were confirmed by the absence of any imaginary frequency. Simulations of UV-Vis spectra were performed using TD-DFT and structures optimized in methanol, since experimental spectra were acquired using this solvent. For the calculations of open-shell systems unrestricted spins were used. All relative enthalpies were calculated at $298.15 \mathrm{~K}$. The values of the solvation enthalpies of proton and electron in methanol were used from literature. ${ }^{30}$

\section{2-Acetyl-1-(4-fluorophenyl)-3-methyl-1H-pyrazolo[1,2-b] phthalazine-5,10-dione (PPD-4)}

Yellow crystals (ethyl acetate/ethanol (1:2)) - mp $208-210{ }^{\circ} \mathrm{C}$; ${ }^{1} \mathrm{H}$ NMR (200 MHz, $\mathrm{CDCl}_{3}$ ) $\delta: 2.12(\mathrm{~s}, 3 \mathrm{H}), 3.08(\mathrm{~d}, J=1.4 \mathrm{~Hz}$, $3 \mathrm{H}), 6.50(\mathrm{q}, J=1.3,1 \mathrm{H}), 7.12-6.99(\mathrm{~m}, 2 \mathrm{H}), 7.53-7.42(\mathrm{~m}, 2 \mathrm{H})$, 7.89-7.78 (m, 2H), 8.26-8.22 (m, 1H), 8.37-8.33 (m, $1 \mathrm{H}) ;{ }^{13} \mathrm{C}$ NMR (50 MHz, $\mathrm{CDCl}_{3}$ ) $\delta: 14.5,30.5,65.3,115.6,116.1,118.8$, $127.3,128.0,128.7,129.5,129.9$, 130.2, 132.3, 133.4, 134.2, 146.1, 154.2, 156.2, 160.4, 165.4, 192.9; IR ( $\left.\mathrm{cm}^{-1}\right): 3581,3059$, 2992, 2917, 1691, 1645, 1599, 1509, 1468, 1415, 1355, 1619, $1291,1274,1219,1108,961,842,701,555 ; \mathrm{C}_{20} \mathrm{H}_{15} \mathrm{FN}_{2} \mathrm{O}_{3}(\mathrm{FW}=$ 350.35): C, 68.57; N, 8.00; H, 4.32\%; found: C, 68.35; N, 7.97; H, $4.33 \%$;

\section{2-Acetyl-1-(4-hydroxyphenyl)-3-methyl-1H-pyrazolo[1,2-} b]phthalazine-5,10-dione (PPD-6)

Yellow powder - mp 205-206 ${ }^{\circ} \mathrm{C} ;{ }^{1} \mathrm{H}$ NMR (200 MHz, $\mathrm{CDCl}_{3}$ ) $\delta$ : 2.09 (s, 3H), 3.07 (d, $J=1.5 \mathrm{~Hz}, 3 \mathrm{H}), 6.44(\mathrm{~d}, J=1.5 \mathrm{~Hz}, 1 \mathrm{H})$, 6.73-7.816.64 (m, 2H), $7.25(\mathrm{~s}, 1 \mathrm{H}), 7.30(\mathrm{~s}, 1 \mathrm{H}), 7.88-7.78(\mathrm{~m}$, $2 \mathrm{H}), 8.26-8.21(\mathrm{~m}, 1 \mathrm{H}), 8.40-8.30(\mathrm{~m}, 1 \mathrm{H}) ;{ }^{13} \mathrm{C}$ NMR $(50 \mathrm{MHz}$, $\left.\mathrm{CDCl}_{3}\right) \delta: 14.5,30.5,65.9,116.0,119.1,127.3,127.8,128.1$, $128.8,129.7,133.5,134.3,145.9,154.3,156.2,156.8,193.7$; IR $\left(\mathrm{cm}^{-1}\right): 3370,2922,2851,1647,1602,1516,1419,1354,1318$, $1290,1275,1105,1015,961,837,791,697,563 ; \mathrm{C}_{20} \mathrm{H}_{16} \mathrm{~N}_{2} \mathrm{O}_{4}(\mathrm{FW}$ $=348.36)$ : C, 68.96; N, 8.04; H, 4.63\%; found: C, 68.69; N, 8.07; $\mathrm{H}, 4.65 \%$;

2-Acetyl-1-(3,4-dihydroxyphenyl)-3-methyl-1H-pyrazolo[1,2b]phthalazine-5,10-dione (PPD-7)

Yellow powder - mp 241-243 ${ }^{\circ} \mathrm{C} ;{ }^{1} \mathrm{H}$ NMR (200 MHz, $\mathrm{CDCl}_{3}$ and $\left.\mathrm{CD}_{3} \mathrm{OD}\right) \delta: 2.05(\mathrm{~s}, 3 \mathrm{H}), 3.00(\mathrm{~d}, J=1.5 \mathrm{~Hz}, 3 \mathrm{H}), 6.33(\mathrm{q}, J=$ $1.4 \mathrm{~Hz}, 1 \mathrm{H}), 6.77$ (d, $J=1.7 \mathrm{~Hz}, 2 \mathrm{H}), 6.91-6.88(\mathrm{~m}, 1 \mathrm{H}), 7.83-7.77$ $(\mathrm{m}, 2 \mathrm{H}), 8.19-8.14(\mathrm{~m}, 1 \mathrm{H}), 8.32-8.27(\mathrm{~m}, 1 \mathrm{H}) ;{ }^{13} \mathrm{C}$ NMR (50 $\mathrm{MHz}, \mathrm{CDCl}_{3}$ and $\left.\mathrm{CD}_{3} \mathrm{OD}\right) \delta: 13.8,29.8,65.7,114.9,115.1,119.1$, $120.0,126.7$, 127.2, 127.6, 128.5, 129.2, 133.4, 134.1, 144.9,
145.5, 145.7, 154.1, 156.1, 194.5; IR $\left(\mathrm{cm}^{-1}\right): 3483,3223,1687$, 1637, 1598, 1518, 1470, 1375, 1356, 1289, 1200, 1106, 962, 891, 824, 764, 692, 579; $\mathrm{C}_{20} \mathrm{H}_{16} \mathrm{~N}_{2} \mathrm{O}_{5}(\mathrm{FW}=364.36): \mathrm{C}, 65.93 ; \mathrm{N}, 7.69$; $\mathrm{H}, 4.43 \%$; found: C, 65.75 ; N, 7.66; H, 4.41\%;

\section{2-Acetyl-1-(4-hydroxy-3-methoxyphenyl)-3-methyl-1H-pyrazolo [1,2-b]phthalazine-5,10-dione (PPD-8)}

Yellow powder - mp 230-231 ${ }^{\circ} \mathrm{C} ;{ }^{1} \mathrm{H}$ NMR (200 $\left.\mathrm{MHz}, \mathrm{CDCl}_{3}\right) \delta$ : 2.10 (s, 3H), 3.07 (d, J=1.5 Hz, 3H), 3.90 (s, 3H), 5.80 (br, s, 1H), $6.45(\mathrm{q}, J=1.4 \mathrm{~Hz}, 1 \mathrm{H}), 6.87(\mathrm{~d}, J=8.1 \mathrm{~Hz}, 1 \mathrm{H}), 6.94(\mathrm{dd}, J=8.2$, $1.9 \mathrm{~Hz}, 1 \mathrm{H}), 7.02$ (d, $J=1.8 \mathrm{~Hz}, 1 \mathrm{H}), 7.87-7.76(\mathrm{~m}, 2 \mathrm{H}), 8.30-8.19$ (m, 1H), 8.36-8.31 (m, 1H); ${ }^{13} \mathrm{C}$ NMR (50 MHz, $\left.\mathrm{CDCl}_{3}\right) \delta: 14.4$, 30.5 , 56.1, 65.9, 111.4, 114.7, 118.8, 121.2, 127.3, 127.9, 128.1, $128.9,129.6$, 133.4, 134.1, 145.9, 146.5, 146.7, 154.3, 156.3, 193.5; IR ( $\left.\mathrm{cm}^{-1}\right): 3418,2921,2850,1687,1641,1518,1433,1371$, 1349, 1276, 1196, 1109, 1040, 959, 791, 696, 586; $\mathrm{C}_{21} \mathrm{H}_{18} \mathrm{~N}_{2} \mathrm{O}_{5}$ $(\mathrm{FW}=378.38): \mathrm{C}, 66.66 ; \mathrm{N}, 7.40 ; \mathrm{H}, 4.80 \%$; found: $\mathrm{C}, 66.71 ; \mathrm{N}$, $7.42 ; \mathrm{H}, 4.82 \%$.

\section{2-Acetyl-1-(4-hydroxy-3,5-dimethoxyphenyl)-3-methyl-1 $H$-pyrazolo[1,2-b] phthalazine-5,10-dione (PPD-9)}

Brown solid - mp 95-96 ${ }^{\circ} \mathrm{C} ;{ }^{1} \mathrm{H}$ NMR $\left(200 \mathrm{MHz}, \mathrm{CDCl}_{3}\right) \delta: 2.09$ (s, $3 \mathrm{H}), 3.08$ (d, J=1.1 Hz, 3H), 3.89 (s, 6H), 5.57 (br, s, 1H), 6.44 (d, $J=1.3 \mathrm{~Hz}, 1 \mathrm{H}), 6.70(\mathrm{~s}, 2 \mathrm{H}), 7.85-7.81(\mathrm{~m}, 2 \mathrm{H}), 8.30-8.21(\mathrm{~m}$, $1 \mathrm{H}), 8.38-8.30(\mathrm{~m}, 1 \mathrm{H}) ;{ }^{13} \mathrm{C}$ NMR $\left(50 \mathrm{MHz}, \mathrm{CDCl}_{3}\right) \delta: 14.4,30.5$, 56.5, 66.3, 105.6, 118.6, 127.2, 127.3, 127.9, 128.9, 129.6, 133.4, 134.2, 135.7, 145.9, 147.3, 154.5, 156.3, 193.6; IR ( $\left.\mathrm{cm}^{-1}\right): 3420$, 2939, 2842, 1721, 1687, 1646, 1602, 1516, 1465, 1430, 1355, 1306, 1111, 697; $\mathrm{C}_{22} \mathrm{H}_{20} \mathrm{~N}_{2} \mathrm{O}_{6}(\mathrm{FW}=408.41): \mathrm{C}, 64.70 ; \mathrm{N}, 6.86 ; \mathrm{H}$, 4.94\%; found: C, 64.45; N, 6.89; H, 4.96\%;

\section{2-Acetyl-3-methyl-1-(3,4,5-trimethoxyphenyl)-1H-pyrazolo[1,2-b] phthalazine-5,10-dione (PPD-10)}

Yellow solid - mp 167-169 ${ }^{\circ} \mathrm{C} ;{ }^{1} \mathrm{H}$ NMR $\left(200 \mathrm{MHz}, \mathrm{CDCl}_{3}\right) \delta: 2.12$ $(\mathrm{s}, 3 \mathrm{H}), 3.07$ (d, $J=1.1 \mathrm{~Hz}, 3 \mathrm{H}), 3.81(\mathrm{~s}, 3 \mathrm{H}), 3.86$ (s, 6H), 6.45 (d, $J=1.5 \mathrm{~Hz}, 1 \mathrm{H}), 6.68(\mathrm{~s}, 2 \mathrm{H}), 7.86-7.81(\mathrm{~m}, 2 \mathrm{H}), 8.29-8.25$ (d, $J=$ $1.8 \mathrm{~Hz}, 1 \mathrm{H}), 8.38-8.33(\mathrm{~m}, 1 \mathrm{H}) ;{ }^{13} \mathrm{C}$ NMR (50 MHz, $\left.\mathrm{CDCl}_{3}\right) \delta$ : 14.4 , 30.5, 56.3, 60.7, 66.2, 105.9, 118.7, 127.3, 128.0, 128.9, $129.6,131.7,133.5,134.2,138.9,145.9,153.9,154.5,156.3$, 193.4; IR (cm $\left.{ }^{-1}\right): 3452,2927,1655,1682,1599,1504,1465,1421$, $1353,1315,1255,1199,1128,1042,835,786,698 ; \mathrm{C}_{23} \mathrm{H}_{22} \mathrm{~N}_{2} \mathrm{O}_{6}$ $(\mathrm{FW}=422.44): \mathrm{C}, 65.40 ; \mathrm{N}, 6.63 ; \mathrm{H}, 5.25 \%$; found: $\mathrm{C}, 65.26 ; \mathrm{N}$, $6.65 ; \mathrm{H}, 5.23 \%$;

\section{X-ray crystal structure determination of PPD-4}

Single-crystal X-ray diffraction data for PPD-4 were collected at an Oxford Gemini $S$ diffractometer equipped with a CCD detector, using monochromatized MoK $\alpha$ radiation $(\lambda=0.71073$ $\AA$ ). Data reduction and empirical absorption correction were performed with CrysAlisPRO. ${ }^{31}$ The structure was solved by direct methods using SHELXS and refined on F2 by full-matrix least-squares using SHELXL. ${ }^{32}$ All non-hydrogen atoms were refined anisotropically. $\mathrm{H}$ atoms were placed in geometrically calculated positions and refined using the riding model with $U_{\text {iso }}$ values constrained to $1.2 U_{\text {eq }}$ or $1.5 U_{\text {eq }}$ of the parent $\mathrm{C}$ 
atoms. The PARST ${ }^{33}$ and PLATON ${ }^{34}$ software were used to perform geometrical calculation, while ORTEP3 (ref. 35) and was employed for molecular graphics. Crystallographic details for structure analysis of the PPD-4 are summarized in Table S6. $\dagger$

CCDC 1584133 contains the supplementary crystallographic data for compound PPD-4.

\section{DPPH free radical scavenging assay}

The free radical scavenging activity of the examined compounds was performed using the DPPH method, according to ref. 36 . DPPH solution ( $1 \mathrm{~mL}, 0.05 \mathrm{mM})$ in methanol was mixed with the tested compound $(20 \mu \mathrm{L}$ of compound solution in DMSO and $980 \mu \mathrm{L}$ of methanol). The reaction mixture was allowed to stand at room temperature for 20 and $60 \mathrm{~min}$. After incubation the absorbance was determined spectrophotometrically at $517 \mathrm{~nm}$. As control solution, methanol was used. $\mathrm{IC}_{50}$ values represent the concentration necessary to obtain $50 \%$ of a maximum scavenging capacity. NDGA was used as positive control. All measurements were performed on three replicates. The results presented as mean values \pm standard deviation (SD) of three independent measurements.

\section{Conflicts of interest}

There are no conflicts to declare.

\section{Acknowledgements}

This investigation was supported by the Ministry of Education, Science and Technological Development of the Republic of Serbia project No. 172016 and 172014.

\section{Notes and references}

1 (a) M. Asif, Curr. Med. Chem., 2012, 19, 2984; (b) A. Marella, M. Shaquiquzzaman, M. Akhter, G. Verma and M. M. Alam, J. Enzyme Inhib. Med. Chem., 2015, 30, 597; (c) K. R. A. Abdellatif, M. T. Elsaady, S. A. Abdel-Aziz and A. H. A. Abusabaa, J. Enzyme Inhib. Med. Chem., 2016, 31, 1545; (d) M. J. Naim, O. Alam, F. Nawaz, M. J. Alam and P. Alam, J. Pharm. BioAllied Sci., 2016, 8, 2.

2 (a) J. Li, Y. F. Zhao, X. Y. Yuan, J. X. Xu and P. Gong, Molecules, 2006, 11, 574; (b) I. A. Al-Suwaidan, N. I. AbdelAziz, A. S. El-Azab, M. A.-A. El-Sayed, A. M. Alanazi, M. B. El-Ashmawy and A. A.-M. Abdel-Aziz, J. Enzyme Inhib. Med. Chem., 2015, 30, 679.

3 L. Zhang, L. P. Guan, X. Y. Sun, C. X. Wei, K. Y. Chai and Z. S. Quan, Chem. Biol. Drug Des., 2009, 73, 313.

4 J. Sinkkonen, V. Ovcharenko, K. N. Zelenin, I. P. Bezhan, B. A. Chakchir, F. Al-Assar and K. Pihlaja, Eur. J. Org. Chem., 2002, 6, 2046.

5 C. K. Ryu, R. E. Park, M. Y. Ma and J. H. Nho, Bioorg. Med. Chem. Lett., 2007, 17, 2577.

6 S. B. Jadhava, S. Fatemaa, M. A. I. Patela and M. Farooqui, Chem. Biol. Interface, 2017, 7, 134.
7 K. Abouzid, M. A. Hakeem, O. Khalil and Y. Maklad, Bioorg. Med. Chem., 2008, 16, 382.

8 (a) S. S. El-Saka, A. H. Soliman and A. M. Imam, Afinidad, 2009, 66, 167; (b) M. Abbasi, S. M. R. Nazifi, Z. S. Nazifi and A. R. Massah, J. Chem. Sci., 2017, 129, 1257.

9 D. S. Raghuvanshi and K. N. Singh, Tetrahedron Lett., 2011, 52, 5702.

10 R. Ghahremanzadeh, S. Ahadi, M. Sayyafi and A. Bazgir, Tetrahedron Lett., 2008, 49, 4479.

11 (a) R. Ghahremanzadeh, G. I. Shakibaei and A. Bazgir, Synlett, 2008, 1129; (b) M. R. Nabid, S. J. T. Rezaei, R. Ghahremanzadeh and A. Bazgir, Ultrason. Sonochem., 2010, 17, 159.

12 L.-P. Liu, J.-M. Lu and M. Shi, Org. Lett., 2007, 9, 1303.

13 (a) B. Maleki and S. S. Ashrafi, J. Mex. Chem. Soc., 2014, 58, 159; (b) A. R. Kiasat, S. Noorizadeh, M. Ghahremani and S. J. Saghanejad, J. Mol. Struct., 2013, 1036, 216; (c) G. Sabitha, C. Srinivas, A. Raghavendar and J. S. Yadav, Helv. Chim. Acta, 2010, 93, 1375; (d) E. Mosaddegh and A. Hassankhani, Tetrahedron Lett., 2011, 52, 488; (e) M. Kidwai, R. Chauhan and A. Jahan, Chin. Sci. Bull., 2012, 57, 2273; $(f)$ H. J. Wang, X. N. Zhang and Z. H. Zhang, Monatsh. Chem., 2010, 141, 425; (g) A. Corma and H. Garcia, Catal. Today, 1997, 38, 257; (h) R. G. Vaghei, R. K. Nami, Z. K. Semiromi, M. Amiri and M. Ghavidel, Tetrahedron, 2011, 67, 1930; (i) H. R. Shaterian, M. Ghashang and M. Feyzi, Appl. Catal., A, 2008, 345, 128; (j) M. Sayyafi, M. Sayyedhamzeh, H. R. Khavasi and A. Bazgir, Tetrahedron, 2008, 64, 2375.

14 J. M. Khurana and D. Magoo, Tetrahedron Lett., 2009, 50, 7300 .

15 (a) G. Zhao, T. Jiang, H. Gao, B. Han, J. Huang and D. Sun, Green Chem., 2004, 6, 75; (b) S. Sahoo, T. Joseph and S. B. Halligudi, J. Mol. Catal. A: Chem., 2006, 244, 179; (c) A. Kumar and S. S. Pawar, J. Org. Chem., 2004, 69, 1419; (d) A. Aggarwal, N. L. Lancaster, A. R. Sethi and T. Welton, Green Chem., 2002, 4, 517; (e) D. Fang, K. Gong, D. Zhang and Z. Liu, Monatsh. Chem., 2009, 140, 1325; $(f)$ D. Yin, C. Li, L. Tao, N. Yu, S. Hu and D. Yin, J. Mol. Catal. A: Chem., 2006, 245, 260.

16 (a) M. Sayyafi, M. Seyyedhamzeh, H. R. Khavasi and A. Bazgir, Tetrahedron, 2008, 64, 2375; (b) J. Davarpanahab and A. R. Kiasat, $R S C A d v$., 2015, 5, 7986; (c) A. R. Kiasat and J. Davarpanah, J. Mol. Catal. A: Chem., 2013, 373, 46.

17 V. P. Petrović, D. Simijonović, M. N. Živanović, J. V. Košarić, Z. D. Petrović, S. Marković and S. D. Marković, RSC Adv., 2014, 4, 24635.

18 D. Simijonović, Z. D. Petrović and V. P. Petrović, J. Mol. Liq., 2013, 179, 98.

19 L. Valgimigli, R. Amorati, M. G. Fumo, G. A. DiLabio, G. F. Pedulli, K. U. Ingold and D. A. Pratt, J. Org. Chem., 2008, 73, 1830.

20 (a) A. T. De Pinedo, P. Peňalver and J. C. Morales, Food Chem., 2007, 103, 55; (b) M. C. Foti, E. R. Johnson, M. R. Vinquist, J. S. Wright, L. R. C. Barclay and K. U. Ingold, J. Org. Chem., 2002, 67, 5190; (c) M. C. Foti, 
L. R. C. Barclay and K. U. Ingold, J. Am. Chem. Soc., 2002, 124, 12881.

21 (a) J. S. Wright, E. R. Johnson and G. A. DiLabio, J. Am. Chem. Soc., 2001, 123, 1173; (b) M. Lucarini, V. Mugnaini and G. F. Pedulli, J. Org. Chem., 2002, 67, 928.

22 (a) A. Galano, G. Mazzone, R. Alvarez-Diduk, T. Marino, J. R. Alvarez-Idaboy and N. Russo, Annu. Rev. Food Sci. Technol., 2016, 7, 335; (b) A. Galano, J. Mex. Chem. Soc., 2015, 59, 231; (c) A. Pé rez-Gonzá lez, A. Galano and J. Raú Alvarez-Idaboy, New J. Chem., 2014, 38, 2639; (d) J. Rimarč̉̉, V. Lukeš, E. Klein and M. Ilčin, J. Mol. Struct.: THEOCHEM, 2010, 952, 25; (e) E. Klein, V. Lukeš and M. Ilčin, Chem. Phys., 2007, 336, 51; $(f)$ Z. Marković, J. Đorović, Z. D. Petrović, V. Petrović and D. Simijonović, J. Mol. Model., 2015, 21, 293; (g) J. Xie and K. M. Schaich, J. Agric. Food Chem., 2014, 62, 4251; (h) Z. D. Petrović, D. Simijonović, J. Đorovi, V. Milovanović, Z. Marković and V. P. Petrović, ChemistrySelect, 2017, 2, 11187.

23 A. Amić, Z. Marković, J. M. D. Marković, S. Jeremić, B. Lučić and D. Amić, Comput. Biol. Chem., 2016, 65, 45.

24 H.-D. Belitz, W. Grosch and P. Schieberle, Food Chemistry, Springer Berlin Heidelberg, Berlin, Heidelberg, 2009.

25 Z. Marković, D. Milenković, J. Đorović, J. M. Dimitrić Marković, V. Stepanić, B. Lučić and D. Amić, Food Chem., 2012, 134, 1754.

26 (a) X. Li, P. Fang, J. Mai, E. T. Choi, H. Wang and X. Yang, J. Hematol. Oncol., 2013, 6, 19; (b) F. Muller, J. Am. Aging Assoc., 2000, 23, 227.

27 M. J. Frisch, W. G. Trucks, B. H. Schlegel, E. G. Scuseria, A. M. Robb, R. J. Cheeseman, G. Scalmani, V. Barone, B. Mennucci, A. G. Petersson, H. Nakatsuji, M. Caricato, X. Li, P. H. Hratchian, F. A. Izmaylov, J. Bloino, G. Zheng,
L. J. Sonnenberg, M. Hada, M. Ehara, K. Toyota, R. Fukuda, J. Hasegawa, M. Ishida, T. Nakajima, Y. Honda, O. Kitao, H. Nakai, T. Vreven, A. J. Montgomery Jr., E. J. Peralta, F. Ogliaro, M. Bearpark, J. J. Heyd, E. Brothers, N. K. Kudin, N. V. Staroverov, R. Kobayashi, J. Normand, K. Raghavachari, A. Rendell, C. J. Burant, S. S. Iyengar, J. Tomasi, M. Cossi, N. Rega, J. M. Millam, M. Klene, J. E. Knox, J. B. Cross, V. Bakken, C. Adamo, J. Jaramillo, R. Gomperts, E. R. Stratmann, O. Yazyev, J. A. Austin, R. Cammi, C. Pomelli, W. J. Ochterski, L. R. Martin, K. Morokuma, G. V. Zakrzewski, A. G. Voth, P. Salvador, J. J. Dannenberg, S. Dapprich, D. A. Daniels, O. Farkas, B. J. Foresman, V. J. Ortiz, J. Cioslowski and J. D. Fox, Gaussian 09 Rev C, Gaussian Inc., Wallingford, 2009.

28 (a) C. Lee, W. Yang and R. G. Parr, Phys. Rev. B: Condens. Matter Mater. Phys., 1988, 37, 785; (b) A. D. Becke, J. Chem. Phys., 1993, 98, 5648.

29 A. V. Marenich, C. J. Cramer and D. G. Truhlar, J. Phys. Chem., 2009, 113, 4538.

30 Z. Marković, J. Tošović, D. Milenković and S. Marković, Comput. Theor. Chem., 2016, 1077, 11.

31 CrysAlisPRO Software system, Agilent Technologies UK Ltd., Oxford, England, 2014.

32 G. M. Sheldrick, Acta Crystallogr., Sect. C: Struct. Chem., 2015, $71,3$.

33 M. Nardelli, J. Appl. Crystallogr., 1995, 28, 659.

34 A. L. Spek, J. Appl. Crystallogr., 2003, 36, 7.

35 L. J. Farrugia, J. Appl. Crystallogr., 2012, 45, 849.

36 C. Kontogiorgis and D. Hadjipavlou-Litina, J. Enzyme Inhib. Med. Chem., 2003, 18, 63. 